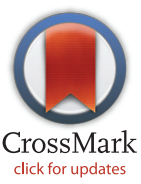

click for updates
RESEARCH ARTICLE

\section{The Translocation Domain of Botulinum Neurotoxin A Moderates the Propensity of the Catalytic Domain to Interact with Membranes at Acidic $\mathrm{pH}$}

\author{
Anne Araye ${ }^{1}$, Amélie Goudet ${ }^{1}$, Julien Barbier ${ }^{1}$, Sylvain Pichard ${ }^{1}$, Bruno Baron ${ }^{2}$, \\ Patrick England $^{2}$, Javier Pérez ${ }^{3}$, Sophie Zinn-Justin ${ }^{4}$, Alexandre Chenal ${ }^{5}$, Daniel Gillet ${ }^{1 *}$ \\ 1 CEA, iBiTec-S/SIMOPRO, CEA-Saclay, Paris Saclay University, LabEx LERMIT, F-91191 Gif-sur-Yvette, \\ France, 2 Institut Pasteur, Proteopole, Plateforme de Biophysique des Macromolécules et de leurs \\ Interactions (PFBMI), 25-28 rue du Dr Roux, F-75724 Paris cedex 15, France, 3 Synchrotron Soleil, BP 48, \\ F-91192 Gif-sur-Yvette Cedex, France, 4 CEA, iBiTec-S/LBSR, CEA-Saclay, F-91191 Gif-sur-Yvette, \\ France, 5 Institut Pasteur, Unité de Biochimie des Interactions Macromoléculaires, UMR 3528, 25-28 rue du \\ Dr Roux, F-75724 Paris cedex 15, France \\ * daniel.gillet@cea.fr
}

\section{Gopen ACcess}

Citation: Araye A, Goudet A, Barbier J, Pichard S, Baron B, England P, et al. (2016) The Translocation Domain of Botulinum Neurotoxin A Moderates the Propensity of the Catalytic Domain to Interact with Membranes at Acidic pH. PLoS ONE 11(4): e0153401. doi:10.1371/journal.pone.0153401

Editor: Michel R. Popoff, Institute Pasteur, FRANCE

Received: November 27, 2015

Accepted: March 29, 2016

Published: April 12, 2016

Copyright: @ 2016 Araye et al. This is an open access article distributed under the terms of the Creative Commons Attribution License, which permits unrestricted use, distribution, and reproduction in any medium, provided the original author and source are credited.

Data Availability Statement: All relevant data are within the paper and its Supporting Information files.

Funding: This work was funded by the joint ministerial program of $R \& D$ against CBRNE threats. SIMOPRO is a member of the Laboratory of Excellence LERMIT supported by a grant from the Agence Nationale de la Recherche (ANR-10-LABX33). The funders had no role in study design, data collection and analysis, decision to publish, or preparation of the manuscript.

Competing Interests: The authors have declared that no competing interests exist.

\section{Abstract}

Botulinum neurotoxin $A$ (BoNT/A) is composed of three domains: a catalytic domain (LC), a translocation domain $\left(\mathrm{H}_{\mathrm{N}}\right)$ and a receptor-binding domain $\left(\mathrm{H}_{\mathrm{C}}\right)$. Like most bacterial toxins BoNT/A is an amphitropic protein, produced in a soluble form that is able to interact, penetrate and/or cross a membrane to achieve its toxic function. During intoxication BoNT/A is internalized by the cell by receptor-mediated endocytosis. Then, LC crosses the membrane of the endocytic compartment and reaches the cytosol. This translocation is initiated by the low $\mathrm{pH}$ found in this compartment. It has been suggested that LC passes in an unfolded state through a transmembrane passage formed by $\mathrm{H}_{\mathrm{N}}$. We report here that acidification induces no major conformational change in either secondary or tertiary structures of $L C$ and $\mathrm{H}_{\mathrm{N}}$ of BoNT/A in solution. GdnHCl-induced denaturation experiments showed that the stability of $L C$ and $H_{N}$ increases as $\mathrm{pH}$ drops, and that $\mathrm{H}_{\mathrm{N}}$ further stabilizes $L C$. Unexpectedly we found that $L C$ has a high propensity to interact with and permeabilize anionic lipid bilayers upon acidification without the help of $\mathrm{H}_{\mathrm{N}}$. This property is downplayed when $\mathrm{LC}$ is linked to $H_{N} \cdot H_{N}$ thus acts as a chaperone for LC by enhancing its stability but also as a moderator of the membrane interaction of LC.

\section{Introduction}

Botulinum neurotoxin (BoNT) secreted by Clostridium botulinum is the causative agent of botulism, a neuroparalytic disease. There are seven serologically distinct BoNT isoforms designated as A to G [1]. These toxins are considered to be the most potent among bacterial, animal, plant toxins and chemical compounds. As there is no available specific cure or vaccine against 
botulism, BoNTs are also considered as a potential biological weapon [2]. It is also a remarkable cure for numerous neuromuscular and neuronal diseases [3]. BoNTs are synthesized as a single soluble polypeptide chain of $150 \mathrm{kDa}$. This inactive precursor is cleaved either by a clostridial or tissue protease generating two polypeptides chains linked through a disulfide bound. The light chain (LC, $50 \mathrm{kDa}$ ) corresponds to the catalytic domain with a zinc endopeptidase activity [3-5]. The heavy chain ( $\mathrm{HC}, 100 \mathrm{kDa})$ encompasses two functional domains: the translocation domain at the $\mathrm{N}$-terminus $\left(\mathrm{H}_{\mathrm{N}}\right)$ and the receptor-binding domain at the $\mathrm{C}$-terminus $\left(\mathrm{H}_{\mathrm{C}}\right)[4,6,7]$. The three domains are critical for cell intoxication by BoNTs. $\mathrm{H}_{\mathrm{C}}$ allows recognition of neuronal cells by a double anchorage to a ganglioside and a protein receptor [8-11]. Following binding to its receptors, BoNT is internalized through clathrin-dynamin mediated endocytosis of recycling neurosecretion vesicles [12]. Inside the endocytic compartments, $\mathrm{H}_{\mathrm{N}}$ assists the translocation of LC into the cytosol, upon acidification [13-15]. LC cleaves SNARE proteins involved in neurotransmitter release leading to the inhibition of acetylcholine release at the neuromuscular junction, resulting in flaccid paralysis [16].

The translocation, a key step of the intoxication, is still poorly understood. This step raises the issue of the physico-chemical and structural properties used by amphitropic proteins to interact and cross biological membranes. Among bacterial toxins, several mechanisms can be found such as conformational change and oligomerization for the pore-forming toxins [17]. Translocating toxins like BoNT/A have a domain, $\mathrm{H}_{\mathrm{N}}$, dedicated to the membrane crossing of their catalytic domain $\mathrm{H}_{\mathrm{N}}$. $\mathrm{H}_{\mathrm{N}}$ may act as a channel that would provide a way through the membrane for an unfolded LC; this is the case for the anthrax toxin [18]. For the diphtheria toxin, $\mathrm{H}_{\mathrm{N}}$ acts like a chaperone that helps LC to achieve a partially folded state necessary for membrane binding and penetration [19].

The details of LC membrane-crossing mechanism remain largely unknown. In the past decade based on electrophysiology measurements, it has been proposed that $\mathrm{H}_{\mathrm{N}}$ could ensure a dual channel and chaperone activity. According to this model, LC would unfold through the channel formed by $\mathrm{H}_{\mathrm{N}}$ to reach the cytosol $[20,21]$. An alternative model suggests that $\mathrm{H}_{\mathrm{N}}$ could constitute a hydrophilic "cleft" that would allow the hydrophilic regions of LC to cross the membrane $[15,22]$. The aims of this study were to characterize the capacity of $\mathrm{LC}$ and $\mathrm{H}_{\mathrm{N}}$ of BoNT/A to interact and penetrate a membrane and to determine how $\mathrm{LC}$ and $\mathrm{H}_{\mathrm{N}}$ of BoNT/ A influence each other during the successive steps leading to membrane binding and penetration as $\mathrm{pH}$ drops. We investigated by spectroscopic methods the structure and stability of the domains in solution. We monitored the membrane binding and penetration capacities of the domains, isolated or linked together as in the native toxin. We found that acidification stabilizes the domains. Unexpectedly LC interacts with and permeabilizes model membranes more efficiently than $\mathrm{H}_{\mathrm{N}}, \mathrm{H}_{\mathrm{N}}$ further enhances the stabilization of $\mathrm{LC}$ induced by acidic $\mathrm{pH}$ and acts as a moderator of LC in its interaction with the membrane.

\section{Methods}

\section{Cloning, production, and purification of recombinant $\mathrm{LC}, \mathrm{H}_{\mathrm{N}}$ and tandem $\mathrm{LC}-\mathrm{H}_{\mathrm{N}}$ constructs of BoNT/A}

Cloning of the Tm fragment, corresponding to the sequence encoding for fragment C454/ S-S877 of $\mathrm{H}_{\mathrm{N}}$, has been described previously [23]. A synthetic gene encoding residues M1S877 of both LC and $\mathrm{H}_{\mathrm{N}}$ domains of BoNT/A (named LC- $\mathrm{H}_{\mathrm{N}}$ ) was purchased from Geneart (Regensburg, Germany) and cloned in a pCR-Script plasmid. The sequence was optimized for the expression in Escherichia coli. A potential Shine Delgarno sequence was also mutated. Two restriction sites for BamHI at the 5' end and for AvaI at the 3' end were introduced. The plasmid pCR-Script encoding for LC- $\mathrm{H}_{\mathrm{N}}$ was amplified and then digested by BamHI and AvaI. 
The fragment corresponding to $\mathrm{LC}-\mathrm{H}_{\mathrm{N}}$ was cloned in the $\mathrm{pQE}-81 \mathrm{~L}$ (Qiagen) plasmid digested also by BamHI and AvaI. LC was obtained by site directed mutagenesis on the pQE-81L-LC$\mathrm{H}_{\mathrm{N}}$ plasmid in order to introduce a stop codon at position 426 of $\mathrm{LC}-\mathrm{H}_{\mathrm{N}}$. The primers used for mutagenesis were $5^{\prime}$-CCGGCCTGTTCGAATTCTAAAAACTGCTGTGTGTTCGTGGC- $3^{\prime}$ and 5' -GCCACGAACACACAGCAGTTTtTAGAATTCGAACAGGCCGG-3' ${ }^{\prime}$. All plasmids, whose sequence was verified, code for a recombinant protein with a His-tag at the $\mathrm{N}$-terminal end. The E. coli strain M15 was used as the host for recombinant protein production.

Expression and purification of the Tm fragment of $\mathrm{H}_{\mathrm{N}}$ has been described previously [23]. The Tm protein corresponds to the activated form of the BoNT/A $\mathrm{H}_{\mathrm{N}}$, i.e. $\mathrm{H}_{\mathrm{N}}$ following proteolytic cleavage between LC and HC, before residue C454 (S1 Fig).

We have chosen to work with 1-425 LC since 1-448 LC was reported to precipitate upon storage [24] 1-425 LC was shown to have proper structure and enzymatic activity [25,26]. LC of BoNT/A expression was performed by inoculation of $1 \mathrm{~L}$ of Terrific Broth medium (Difco, Detroit, USA) with $15 \mathrm{~mL}$ of an overnight culture performed at $28^{\circ} \mathrm{C}$. Induction was started at an optical density at $600 \mathrm{~nm}\left(\mathrm{OD}_{600}\right)$ of 0.8 by addition of $1 \mathrm{mM}$ of isopropyl1-thio-b-D-galactopyranoside and carried out overnight at $16^{\circ} \mathrm{C}$. The cultures were centrifuged at 5,000 g for $45 \mathrm{~min}$ and the pellet was solubilized in a $20 \mathrm{mM}$ Tris/ $\mathrm{HCl}, 500 \mathrm{mM}$ $\mathrm{NaCl}, 10 \mathrm{mM}$ imidazole buffer at $\mathrm{pH}$ 7.9. Recombinant proteins were extracted by biochemical lysis of the bacteria with $10 \mathrm{mg}$ of lysozyme for 1 hour followed by mechanical lysis using a cell disruption apparatus (Constant Systems Ltd, UK). LC was purified from the soluble fraction of the lysate using a His-Trap HP $5 \mathrm{~mL}$ column and an Äkta purifier system (GE Healthcare, USA). The protein was eluted with a $20 \mathrm{mM}$ Tris/ $\mathrm{HCl}, 500 \mathrm{mM} \mathrm{NaCl}, 250 \mathrm{mM}$ imidazole buffer at $\mathrm{pH}$ 7.9. The sample was then subjected to a dialysis in a $10 \mathrm{mM} \mathrm{Tris} / \mathrm{HCl}$, $20 \mathrm{mM} \mathrm{NaCl}$ buffer at $\mathrm{pH} 7.8$ before cation exchange chromatography using a Hi-TrapQ HP $5 \mathrm{~mL}$ column (GE Healthcare, USA). The protein was eluted with a $10 \mathrm{mM}$ Tris/ $\mathrm{HCl}, 150$ $\mathrm{mM} \mathrm{NaCl}$ buffer at $\mathrm{pH}$ 7.8.

The expression of $\mathrm{LC}-\mathrm{H}_{\mathrm{N}}$ was performed by inoculation of $1 \mathrm{~L}$ of Terrific Broth medium with $25 \mathrm{~mL}$ of an overnight culture performed at $37^{\circ} \mathrm{C}$. At an $\mathrm{OD}_{600}$ of 0.3 , the culture was placed at $15^{\circ} \mathrm{C}$. The induction was started at an $\mathrm{OD}_{600}$ of 0.6 by addition of $1 \mathrm{mM}$ of isopropyl1-thio-b-D-galactopyranoside and carried out overnight at $15^{\circ} \mathrm{C}$. The culture was centrifuged at $5,000 \mathrm{~g}$ for $45 \mathrm{~min}$ and the pellet was solubilized in a $20 \mathrm{mM} \mathrm{Na}_{2} \mathrm{HPO}_{4} / \mathrm{NaH}_{2} \mathrm{PO}_{4}, 500 \mathrm{mM}$ $\mathrm{NaCl}, 10 \mathrm{mM}$ imidazole buffer at $\mathrm{pH}$ 8. Recombinant proteins were extracted by biochemical lysis with $10 \mathrm{mg}$ of lysozyme for 1 hour followed by mechanical lysis using a cell disruption apparatus (Constant Systems Ltd, UK). LC- $\mathrm{H}_{\mathrm{N}}$ protein was purified from the soluble fraction of the lysate using a His-Trap HP $5 \mathrm{~mL}$ column and an Äkta purifier system. The protein was eluted with a $20 \mathrm{mM} \mathrm{Na}_{2} \mathrm{HPO}_{4} / \mathrm{NaH}_{2} \mathrm{PO}_{4}, 500 \mathrm{mM} \mathrm{NaCl}, 50 \mathrm{mM}$ imidazole buffer at $\mathrm{pH} 8$. The sample was then subjected to a size exclusion chromatography using a Sephacryl S200 26/ $10300 \mathrm{~mL}$ column (GE Healthcare, USA) with a $20 \mathrm{mM}$ sodium phosphate, $150 \mathrm{mM} \mathrm{NaCl}$, buffer at $\mathrm{pH} 8$.

For all proteins, purification buffer was exchanged by dialysis with a $5 \mathrm{mM}$ phosphate/citrate buffer at $\mathrm{pH} 7$ and were kept at $-20^{\circ} \mathrm{C}$ for $\mathrm{LC}-\mathrm{H}_{\mathrm{N}}$ and $\mathrm{H}_{\mathrm{N}}$ and at $-80^{\circ} \mathrm{C}$ for LC. Protein concentration was performed by measuring the absorbance of the protein at the ultraviolet wavelength of $278 \mathrm{~nm}$ and using Beer-lambert's law. Molar extinction coefficient of each protein was determined from the protein sequence on the Protein Calculator web resource (http:// protcalc.sourceforge.net).

Coomassie blue staining of the proteins following SDS-PAGE showed that they had been purified nearly to homogeneity. The catalytic activity of $\mathrm{LC}$ and the protein $\mathrm{LC}-\mathrm{H}_{\mathrm{N}}$ was assayed using a fluorogenic peptide mimic of the substrate of BoNT/A [25]. 


\section{Lipid vesicles}

Lipids were purchased from Avanti Polar Lipids (Alabaster, USA). Suspensions of large unilamellar vesicles (LUV) were prepared in $5 \mathrm{mM}$ phosphate/citrate buffer at $\mathrm{pH} 7$ with egg phosphatidylcholine (EPC, 840051) and egg phosphatidic acid (EPA, 840101) at a 9/1 molar ratio for anionic vesicles. After evaporation of the chloroform used for their solubilization, lipids were suspended in phosphate/citrate buffer and then subjected to 5 cycles of freezing in liquid nitrogen followed by thawing at room temperature. This suspension was then filtered twice on a $0.4 \mu \mathrm{m}$ filter and twice on a $0.2 \mu \mathrm{m}$ filters using a homemade extruder. The size of the LUV was checked by dynamic light scattering at $830 \mathrm{~nm}$ by using DynaPro-TC-04 DLS equipment (Protein Solutions, Wyatt Technology, Santa Barbara, CA, USA) and found to be between 140 $\mathrm{nm}$ and $160 \mathrm{~nm}$.

\section{Experimental buffers}

Proteins were kept in $5 \mathrm{mM}$ phosphate/citrate buffer at $\mathrm{pH} 7$ and diluted in a series of phosphate/citrate buffers with varying $\mathrm{pH}$. Permeabilization experiments were performed in $5 \mathrm{mM}$ phosphate/citrate, $100 \mathrm{mM} \mathrm{NaCl}$ buffer of various $\mathrm{pH}$. The concentration of protein was checked by measuring the absorbance at $278 \mathrm{~nm}$. The $\mathrm{pH}$ of the diluted protein samples was checked before and after each experiment.

\section{Circular dichroïsm (CD) spectropolarimetry}

CD experiments were performed on a CD spectropolarimeter model 215 (Aviv, USA). The scans were recorded at a scan rate of $1 \mathrm{~nm} / \mathrm{s}$ (step, $1 \mathrm{~nm}$; integration time, 1s) with a time constant of $100 \mathrm{~ms}$ and a bandwidth of $1 \mathrm{~nm}$. Each spectrum was an average of 5 scans and 3 scans for near-UV and far-UV CD spectra, respectively. A rectangular quartz Suprasil cell of 10 $\mathrm{mm}$ path length and a cylindrical quartz Suprasil cell of $0.2 \mathrm{~mm}$ path length (104B-QS and 121.000-QS, Hellma, Germany) were used for recording CD activity in near-UV and far-UV regions, respectively. $\mathrm{LC}, \mathrm{H}_{\mathrm{N}}$ and $\mathrm{LC}-\mathrm{H}_{\mathrm{N}}$ were diluted to $1 \mathrm{mg} / \mathrm{mL}$ for each protein (corresponding to $10 \mu \mathrm{M}$ for $\mathrm{LC}-\mathrm{H}_{\mathrm{N}}$ and $20 \mu \mathrm{M} \mathrm{LC}$ and $\mathrm{H}_{\mathrm{N}}$ ). The protein concentration (absorbance at $280 \mathrm{~nm}$, Beer-Lambert's law) and pH were also checked after measurement. A $5 \mathrm{mM}$ phosphate/citrate $\mathrm{pH} 5$ dialysis buffer was used as blank in far-UV and near-UV regions and its spectrum was subtracted from protein CD spectra. Data were normalized to the molar peptide bond concentration and path length and expressed as Mean Residue Ellipticity per amino acid $\left([\theta]\right.$ degree $\left.\cdot \mathrm{cm}^{2} \cdot \mathrm{dmol}^{-1} \cdot \mathrm{aa}^{-1}\right)$ for far-UV CD and as Mean Residue Ellipticity $\left([\theta]\right.$ degree. $\mathrm{cm}^{2}$. $\mathrm{dmol}^{-1}$ ) for near-UV CD.

\section{Small angle X-ray scattering (SAXS) experiments}

SAXS samples were prepared in $5 \mathrm{mM}$ phosphate/citrate, $150 \mathrm{mM} \mathrm{NaCl} \mathrm{pH} 7$ or pH 4 . The initial protein concentration of the samples was $10 \mathrm{mg} / \mathrm{ml}$. Prior to data collection, these samples were injected on the online HPLC system of the SWING Beamline at Synchrotron SOLEIL (Gif-sur-Yvette) to eliminate aggregates. Synchrotron radiation X-ray scattering data were collected at $17^{\circ} \mathrm{C}$ following standard procedures of the SWING Beamline and were processed with FOXTROT (from SWING beamline) and PRIMUS (Primary analysis and Manipulation with Small Angle Scattering DATA) from the ATSAS package (http://www.embl-hamburg.de/ biosaxs/software.html). The scattering curves were corrected from scattering due to the buffer and Guinier plots corresponding to each curve were generated (S2 Fig). The pair-distribution functions were computed using the program GNOM from the ATSAS package, allowing determining the radius of gyration and the maximal distance of the molecule. 


\section{Analytical ultracentrifugation (AUC)}

The protein samples in $5 \mathrm{mM}$ phosphate/citrate, $150 \mathrm{mM} \mathrm{NaCl} \mathrm{pH} 7$ or pH 4 were centrifuged at $36,000 \mathrm{rpm}$ in a Beckman Coulter XL-I analytical ultracentrifuge at $20^{\circ} \mathrm{C}$. Detection of the protein concentration as a function of radial position and time was performed by optical density measurements at a wavelength of $280 \mathrm{~nm}$. Sedimentation velocity analysis was performed by continuous size distribution analysis c(s) with Sedfit 12.0 [27]. The following parameters were calculated using Sednterp 1.09 (http://www.jphilo.mailway.com/download.htm) and used to analyze experimental data: partial specific volume $0.738 \mathrm{~mL} . \mathrm{g}^{-1}$, viscosity 0.01016 Poise and density 1.0044 g.mL ${ }^{-1}$. The sedimentation coefficients were corrected for viscosity and expressed as $s$ (value at $20^{\circ} \mathrm{C}$ in water).

\section{Fluorescence spectroscopy}

Tryptophan fluorescence measurements were performed with $\mathrm{LC}, \mathrm{H}_{\mathrm{N}}$ and $\mathrm{LC}-\mathrm{H}_{\mathrm{N}}$ in the absence or presence of LUV. Proteins were diluted to a final concentration of $1 \mu \mathrm{M}$ in a $5 \mathrm{mM}$ phosphate/citrate buffer with varying $\mathrm{pH}$. Experiments with LUV were carried out using a protein/lipid molar ratio of 1/1000. After 2 hours of incubation, fluorescence measurements were performed with an FP-750 spectrofluorimeter (Jasco, Tokyo, Japan). Excitation wavelength was $295 \mathrm{~nm}$. A bandwidth of $5 \mathrm{~nm}$ was used for both excitation and emission beams. The emission spectra were recorded from 310 to $370 \mathrm{~nm}$ at a scan rate of $125 \mathrm{~nm} / \mathrm{min}$. The fluorescence intensity ratio at $360 \mathrm{~nm}$ over $320 \mathrm{~nm}\left(\mathrm{rFI}_{360 / 320}\right)$ represents the average of three values obtained from emission spectra that were corrected for blank measurements [23,28,29].

\section{FRET experiments}

LUV containing dansyl ( $N$-(5-DimethylAminoNaphthalene-1-SulfonYL) were prepared from EPC, EPA, and dansyl-DHPE ( $N$-(5-dimethylaminonaphthalene-1-sulfonyl)-1,2-DiHexadecanoyl-sn-glycero-3-PhosphoEthanolamine, D57, Molecular probes, Life technologies, USA) at a 9/1/0.5 molar ratio. LUV were then prepared as described above. A rectangular Quartz Suprasil cell of $10 \mathrm{~mm}$ path length was used for recording the fluorescence transfer between protein tryptophan donors and the dansyl acceptor. $\mathrm{LC}, \mathrm{H}_{\mathrm{N}}$ or $\mathrm{LC}-\mathrm{H}_{\mathrm{N}}$ were diluted to a final concentration of $0.5 \mu \mathrm{M}$ and mixed with LUV at protein/lipid molar ratio of $1 / 100$ in a $5 \mathrm{mM}$ phosphate/citrate buffer at various $\mathrm{pH}$. Control samples without protein were prepared. After 2 hours of incubation fluorescence measurements were carried out with an FP-750 spectrofluorimeter (Jasco, Tokyo, Japan). Excitation and emission wavelengths were $292 \mathrm{~nm}$ and $520 \mathrm{~nm}$, respectively. Bandwidths of $5 \mathrm{~nm}$ were used for both excitation and emission beams. The emission spectra were recorded from 500 to $540 \mathrm{~nm}$ at a scan rate of $125 \mathrm{~nm} / \mathrm{min}$. Each emission value at $520 \mathrm{~nm}$ is the average calculated from 3 emissions scans. The fluorescence intensity of the dansyl at the plateau was normalized to its initial fluorescence in the absence of protein $[23,28]$. Results represent the average of four independent measurements for each protein.

\section{LUV permeabilization assay}

LUV composed of EPC/EPA at 9/1 molar ratio were prepared as described above, in a $5 \mathrm{mM}$ phosphate/citrate, $100 \mathrm{mM} \mathrm{NaCl} \mathrm{pH} 7$ buffer containing $50 \mathrm{mM}$ sulforhodamine $\mathrm{B}$ (a selfquenching concentration). After extrusion, unincorporated dye was removed by size exclusion chromatography on a PD10 column (Amersham Biosciences, USA) equilibrated with $5 \mathrm{mM}$ phosphate/citrate, $50 \mathrm{mM}$ or $100 \mathrm{mM} \mathrm{NaCl} \mathrm{pH} 7$ buffer. Dye efflux was monitored on a Jasco FP-750 spectrofluorimeter by measuring the increase in fluorescence after adding of $0.1 \mu \mathrm{M}$ of protein to a suspension of LUV at $100 \mu \mathrm{M}$ lipids in $5 \mathrm{mM}$ phosphate/citrate, $100 \mathrm{mM} \mathrm{NaCl}$ 
buffer at different $\mathrm{pH}$ with stirring. Excitation and emission wavelengths were $569 \mathrm{~nm}$ and 586 $\mathrm{nm}$, respectively. Bandwidths of $5 \mathrm{~nm}$ were used for both excitation and emission beams [23].

Fluorescence was normalized with the following equation:

$$
\mathrm{F}(\mathrm{t})_{\text {norm }}=\left(\mathrm{F}(\mathrm{t})-\mathrm{F}_{0}\right) /\left(\mathrm{F}_{\max }-\mathrm{F}_{0}\right)
$$

where $\mathrm{F}_{0}$ is the fluorescence level before protein addition and $\mathrm{F}_{\max }$ the level after addition of Triton X-100 at the end of each assay [23] (S3 Fig).

\section{Chemical protein denaturation by guanidine hydrochloride ( $\mathrm{GdnHCl}$ )}

Stock solutions of $5 \mathrm{mM}$ phosphate/citrate and $7 \mathrm{M} \mathrm{GdnHCl}$ were prepared, their $\mathrm{pH}$ were adjusted using $\mathrm{HCl}$ and $\mathrm{NaOH}$, and filtered. The refractive index of each solution was measured to check the precise $\mathrm{GdnHCl}$ concentration (R-5000 hand refractometer (Atago, Japan)). A range of solutions with $\mathrm{GdnHCl}$ concentrations varying from 0 to $6.8 \mathrm{M}$ for each studied $\mathrm{pH}$ were prepared by dilution of stock solutions in $5 \mathrm{mM}$ phosphate/citrate at the same $\mathrm{pH}$ as the stock solution [30]. LC, $\mathrm{H}_{\mathrm{N}}$ and LC- $\mathrm{H}_{\mathrm{N}}$ proteins were diluted to a final concentration of $1 \mu \mathrm{M}$ in $1.5 \mathrm{~mL}$ with the complete set of $\mathrm{GdnHCl}$ solutions. Samples were incubated overnight before fluorescence measurements on a Jasco FP-750 spectrofluorimeter. Excitation wavelength was $295 \mathrm{~nm}$ with a bandwidth of $5 \mathrm{~nm}$ for both excitation and emission beams. The emission spectra were recorded from 310 to $370 \mathrm{~nm}$ at a scan rate of $125 \mathrm{~nm} / \mathrm{min}$. Fluorescence intensity ratio at $360 \mathrm{~nm}$ over $320 \mathrm{~nm}\left(\mathrm{rFI}_{360 / 320}\right)$ were determined. These wavelengths are related to tryptophan fluorescence intensities in apolar $(320 \mathrm{~nm})$ and solvated $(360 \mathrm{~nm})$ environments, respectively, and the values of $\mathrm{rFI}_{360 / 320}$ are therefore very sensitive to weak polarity changes in the tryptophan surroundings. Each data point represents the average of three values obtained from emission spectra that were corrected for blank measurements. rFI was plotted as a function of $\mathrm{GdnHCl}$ concentration to obtain the $\mathrm{GdnHCl}$-unfolding curves [31]. Curves were analyzed assuming a two-state mechanism and were fitted with the following equation:

$$
\mathrm{y}(\mathrm{D})=1 /\left(1+\exp \left(\left(m \mathrm{D}-\Delta \mathrm{G}^{0}\right) / \mathrm{RT}\right)\right)
$$

where $\Delta G^{0}$ is the free energy in the absence of chaotropic agent, $D$ the denaturant concentration and $m$ the coefficient of dependence of free energy on the denaturant concentration. $m$ is related to the variation of the solvent-accessible surface area between the folded and unfolded states. $\mathrm{D}_{1 / 2}$, the denaturant concentration required to achieve half denaturation was deduced from the expression of free energy at half denaturation:

$$
\Delta \mathrm{G}=-\mathrm{RT} \ln \mathrm{K}=-\Delta \mathrm{G}^{0}+m \mathrm{D}_{1 / 2}=0
$$

Hence,

$$
\mathrm{D}_{1 / 2}=\Delta \mathrm{G}^{0} / m
$$

\section{Results}

Three protein constructs were used in this study: $\mathrm{LC}$ and $\mathrm{H}_{\mathrm{N}}$, corresponding to the isolated catalytic and translocation domains of BoNT/A, and $\mathrm{LC}-\mathrm{H}_{\mathrm{N}}$, corresponding to a truncated BoNT/ A toxin lacking the $\mathrm{H}_{\mathrm{C}}$ domain (Fig 1). In the $\mathrm{LC}-\mathrm{H}_{\mathrm{N}}$ protein construct, $\mathrm{LC}$ and $\mathrm{H}_{\mathrm{N}}$ are linked through a disulfide bond as in the native toxin. The peptide chain linking the domains is cleaved by incubation with trypsin. Cleavage of the peptide chain and integrity of the interdomain disulfide bond were checked by SDS-PAGE under reducing and non-reducing conditions, and Coomassie blue staining (S1 Fig). 


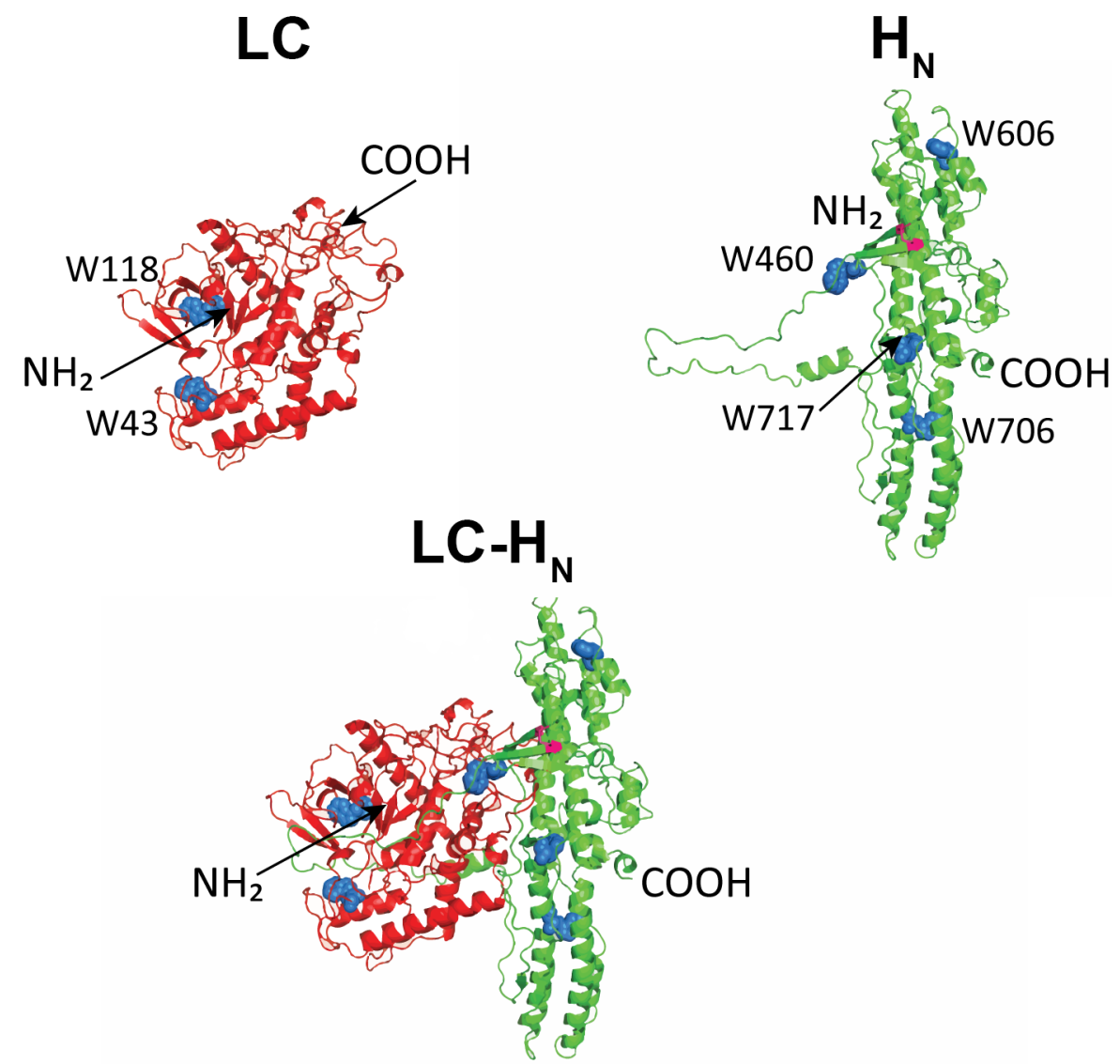

Fig 1. Structure of the recombinant $L C, H_{N}$ and $L C-H_{N}$ proteins of BoNT/A. Ribbon representations of LC, $\mathrm{H}_{\mathrm{N}}$ and LC- $\mathrm{H}_{\mathrm{N}}$ predicted from the structure of BoNT/A (Protein Data Bank file: 3BTA). The N- and Cterminal ends are indicated $\left(\mathrm{NH}_{2}\right.$ and $\left.\mathrm{COOH}\right)$ for each protein. The Trp residues are represented as blue spheres for the three proteins and indicated in C as W43, W118 and as W460, W606, W706 and W717 for $\mathrm{H}_{\mathrm{N}}$.

doi:10.1371/journal.pone.0153401.g001

\section{$\mathrm{LC}$ and $\mathrm{HN}$ of BoNT/A do not undergo any major conformational change upon acidification in solution}

The structure of the proteins constructs was investigated by circular dichroïsm (CD) in the farand near-UV as a function of the $\mathrm{pH}$. In the far-UV (180-260 nm) the CD signal measured for a protein is due mostly to the peptide bonds, so the spectra are indicative of its secondary structure. The far-UV spectra of the three proteins display $\pi-\pi$ and $n-\pi$ characteristics of a $\alpha$-helical content (Fig 2). Analysis of the secondary structure of the three proteins from these CD data is in agreement with the crystal structure of BoNT/A (Fig 1 and Table 1) [4]. The protein CD signal in the near-UV $(250-320 \mathrm{~nm})$ arises from aromatic amino acid side chains constrained in a tertiary structure. LC spectra show a strong negative signal around $280 \mathrm{~nm}$ that may be attributed to Tyr or Trp side chains and two smaller signals at $262 \mathrm{~nm}$ and $268 \mathrm{~nm}$ that may be attributed to Phe side chains. The spectra of $\mathrm{H}_{\mathrm{N}}$ display some weak signals in the absorption regions of Phe, Tyr and Trp side chains as observed previously [23]. LC- $\mathrm{H}_{\mathrm{N}}$ near-UV spectra seem to combine signals from both $\mathrm{LC}$ and $\mathrm{H}_{\mathrm{N}}$.

Upon acidification no remarkable change could be observed in the far-UV spectra for the three proteins. However, a moderate increase of the negative peak intensity around $280 \mathrm{~nm}$ in the near-UV region can be seen at $\mathrm{pH} 3$ for $\mathrm{LC}$ and $\mathrm{LC}-\mathrm{H}_{\mathrm{N}}$. This suggests an increase of the 
Far-UV
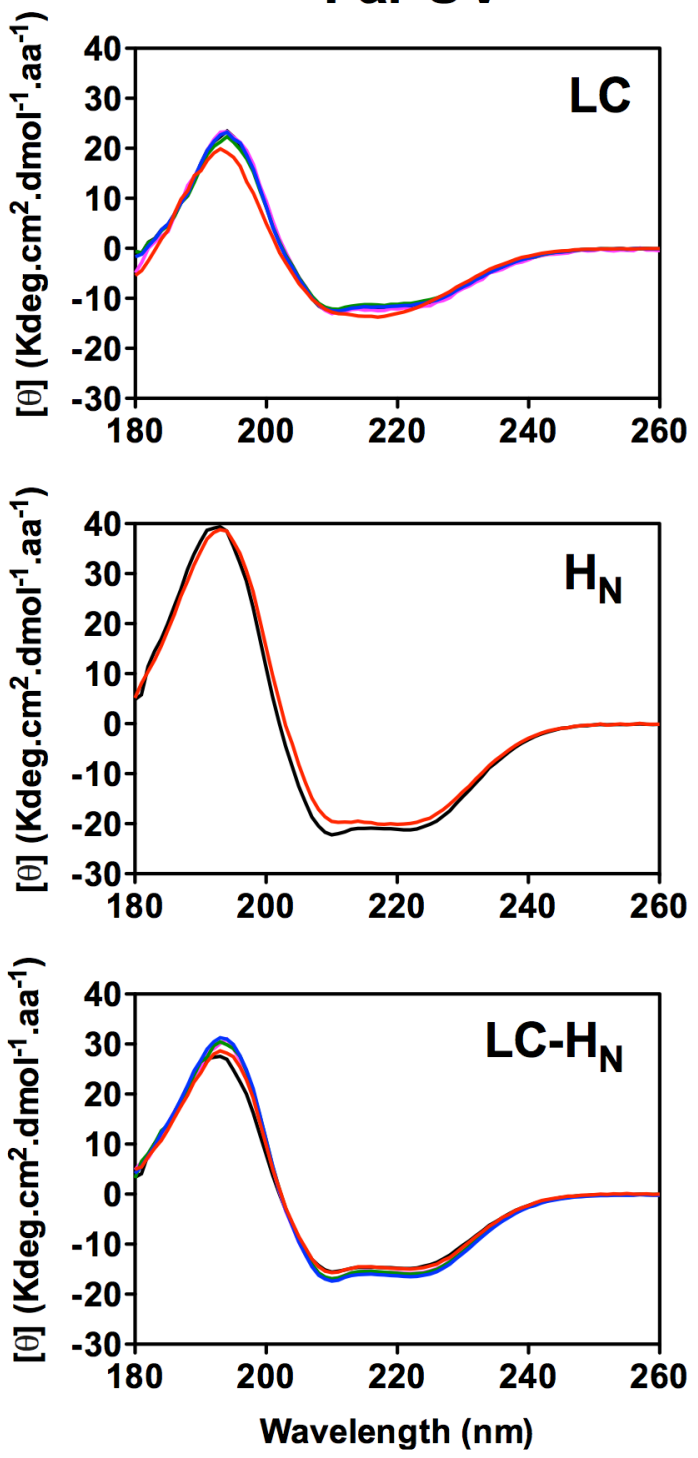

Near-UV
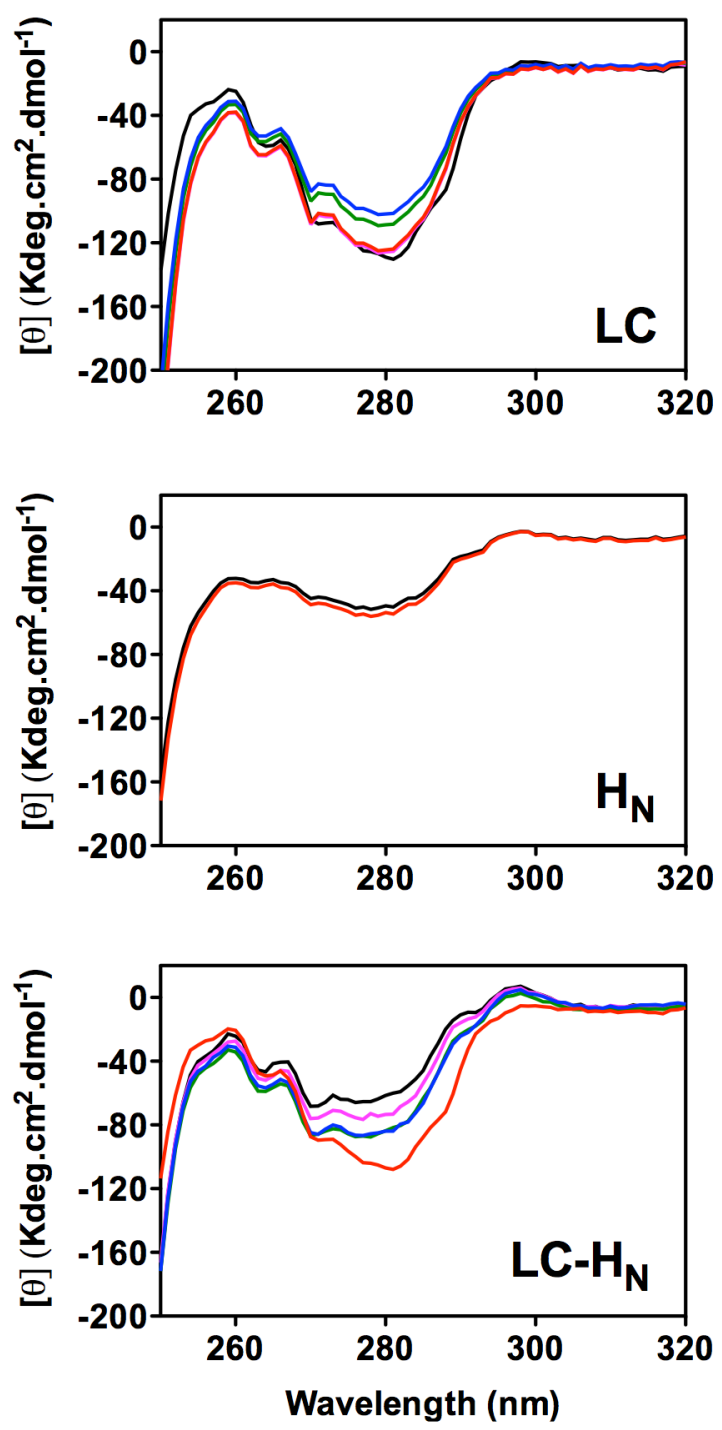

Fig 2. Far and near-UV CD spectra of LC, $\mathbf{H}_{\mathbf{N}}$ and $\mathrm{LC}-\mathrm{H}_{\mathrm{N}}$ proteins of BoNT/A. Left, Far-UV and right Near-UV at various $\mathrm{pH}, \mathrm{pH} 7$ (black curve); $\mathrm{pH} 6$ (pink curve); $\mathrm{pH} 5$ (green curve); $\mathrm{pH} 4$ (blue curve) and pH 3 (red curve).

doi:10.1371/journal.pone.0153401.g002

Table 1. Comparison of the secondary structure of the three proteins based on the far-UV CD spectra at pH 7 (BestSel) with the secondary structure observed in the crystal structure of BoNT/A (3BTA) (STRIDE PDB).

\begin{tabular}{|c|c|c|c|c|c|c|c|c|}
\hline & \multicolumn{4}{|c|}{ BestSel } & \multicolumn{4}{|c|}{ STRIDE PDB } \\
\hline & LC & $H_{N}$ & $L C-H_{N}$ & $\mathrm{LC}+\mathrm{H}_{\mathrm{N}}$ isolated & LC & $\mathrm{H}_{\mathrm{N}}$ & $L C-H_{N}$ & $\mathrm{LC}+\mathrm{H}_{\mathrm{N}}$ isolated \\
\hline alpha & 28.3 & 51.8 & 39.6 & 40.05 & 30.2 & 50.2 & 40.7 & 40.2 \\
\hline beta & 17.3 & 7 & 14.2 & 12.15 & 14 & 1.4 & 9.7 & 7.7 \\
\hline Others ${ }^{1}$ & 54.4 & 41.2 & 46.2 & 47.8 & 55.8 & 48.4 & 49.6 & 52.1 \\
\hline
\end{tabular}

${ }^{1}$ Others: turns and random coils

doi:10.1371/journal.pone.0153401.t001 
tertiary structure constraints surrounding one or several aromatic residues within the LC chain, as it is shared by both proteins.

Altogether, the data show that $\mathrm{LC}, \mathrm{H}_{\mathrm{N}}$ and $\mathrm{LC}-\mathrm{H}_{\mathrm{N}}$ are folded in the range of $\mathrm{pH} 3-7$ with secondary and tertiary structures compatible with those found in the crystal structure of the toxin (pdb 3BTA). Acidification does not trigger any visible conformational change, except around $\mathrm{pH} 3$ within the $\mathrm{LC}$ and $\mathrm{LC}-\mathrm{H}_{\mathrm{N}}$ proteins. The data suggest a moderate gain of tertiary structure within LC without any indication of partial unfolding.

Small Angle X-ray scattering (SAXS) and analytical ultracentrifugation (AUC) provide information on the shape of a protein and the formation of multimers (Fig 3). SAXS gives accurate information about the conformation in solution of macromolecules. The SAXS curves of LC- $\mathrm{H}_{\mathrm{N}}$ at $\mathrm{pH} 7$ and $\mathrm{pH} 4$ are similar indicating that acidification does not trigger any change in the global fold of $\mathrm{LC}-\mathrm{H}_{\mathrm{N}}$ (Fig 3A). The normalized Kratky plots are characteristic of folded proteins (Fig 3B). The Inverse Fourier transform of the scattering intensity yields the distance distribution function, $\mathrm{P}(\mathrm{r})$. Two important parameters can be extracted from this curve: the radius of gyration $\left(\mathrm{R}_{\mathrm{g}}\right)$ and the maximum particle diameter $\left(\mathrm{D}_{\max }\right)$ of the protein $\mathrm{R}_{\mathrm{g}}$ (Fig $\left.3 \mathrm{C}\right)$. The $\mathrm{R}_{\mathrm{g}}$ of $\mathrm{LC}-\mathrm{H}_{\mathrm{N}}$ at $\mathrm{pH} 7$ and $\mathrm{pH} 4$ are close, confirming that $\mathrm{LC}-\mathrm{H}_{\mathrm{N}}$ does not undergo important shape modification upon acidification. Consistently, AUC experiments showed similar sedimentation coefficients $(s)$ for $\mathrm{LC}-\mathrm{H}_{\mathrm{N}}$ at neutral and acid $\mathrm{pH}$ (Fig 3C), suggesting that the overall shape of the protein is not modified by the acidification. In summary, SAXS and AUC data pointed out that the global shape of the $\mathrm{LC}-\mathrm{H}_{\mathrm{N}}$ protein remains the same and that no oligomerization occurred upon acidification.

\section{Acid $\mathrm{pH}$ stabilizes $\mathrm{LC}$ and $\mathrm{HN}$ of BoNT/A}

We investigated the stability of $\mathrm{LC}, \mathrm{H}_{\mathrm{N}}$ and LC- $\mathrm{H}_{\mathrm{N}}$ as a function of $\mathrm{pH}$ by monitoring their unfolding in the presence of increasing concentrations of the chaotropic agent $\mathrm{GdnHCl}$ from 0 to $6.8 \mathrm{M}$ (Fig 4). Chaotropic denaturation was preferred to thermal denaturation to avoid possible aggregation. Unfolding was monitored by measuring the ratio of the fluorescence signal at $360 \mathrm{~nm}$ and $320 \mathrm{~nm}$ of the $\operatorname{Trp}\left(\mathrm{rFI}_{360 / 320}\right.$ that reflects the polarity of Trp environment) as a function of $\mathrm{pH}$. LC contains two Trp at positions 43 and 118 and $\mathrm{H}_{\mathrm{N}}$ contains four Trp at position 460, 606, 707, and 717 (Fig 1). A rFI $\mathrm{H}_{360 / 320}$ that shifts toward high values means that Trp become exposed to the solvent, due to the unfolding of the protein. All proteins exhibit a typical $\mathrm{GdnHCl}$-induced denaturation from the folded state to the unfolded state at neutral $\mathrm{pH}$ (Fig 4). The denaturation curves show only a slight change in the fluorescence of the Trp between 0 and $2 \mathrm{M}$ of $\mathrm{GdnHCl}$. This indicates minor structural changes. A pH drop does not notably change the curves at these concentrations of denaturing agent. In contrast, at higher $\mathrm{GdnHCl}$ concentrations, a clear denaturation transition is observed for all three proteins (Fig 4 for $\mathrm{pH} 7$ and $\mathrm{pH}$ 4). The $\mathrm{rFI}_{360 / 320}$ signal of $\mathrm{LC}-\mathrm{H}_{\mathrm{N}}$ is almost identical to the signal of $\mathrm{H}_{\mathrm{N}}$ indicating that $\mathrm{H}_{\mathrm{N}}$ is dominating the LC- $\mathrm{H}_{\mathrm{N}}$ signal. This may be due to the fact that $\mathrm{H}_{\mathrm{N}}$ contains four Trp as compared to LC that contains only two. In addition, $\mathrm{H}_{\mathrm{N}}$ stabilizes LC (see below), further reducing the contribution of $\mathrm{LC}$ to the change of $\mathrm{rFI}_{360 / 320}$. Interestingly, the denaturation curves are shifted towards higher $\mathrm{GdnHCl}$ concentrations for all the proteins as $\mathrm{pH}$ drops (Fig 4 for $\mathrm{pH} 7$ and $\mathrm{pH} 4$ ). Thermodynamic parameters were extracted by applying a fitting procedure to the experimental data [31]. One or two folding intermediates may appear during denaturation as revealed by slight changes in the slope of the curves. However, fitting according to a three-state model could not be achieved and a two-state model was used as a best approximation. At neutral pH, 2.17 M, 4.25 M and 3.45 M of GdnHCl is needed to achieve half denaturation of LC, $\mathrm{H}_{\mathrm{N}}$ and $\mathrm{LC}-\mathrm{H}_{\mathrm{N}}$, respectively (Fig 4 , inset tables). These values of $\mathrm{D}_{1 / 2}$ increase as $\mathrm{pH}$ drops (shown Fig 4 for $\mathrm{pH}$ 4). At $\mathrm{pH} 4$, these $\mathrm{D}_{1 / 2}$ concentrations are $3.27 \mathrm{M}, 4.76 \mathrm{M}$ and $4.85 \mathrm{M}$ 


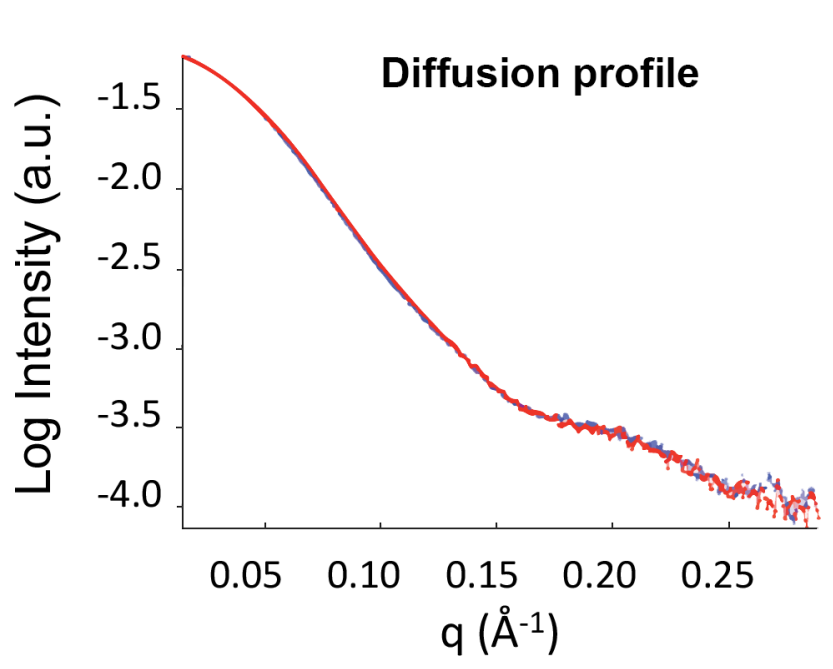

\section{A}

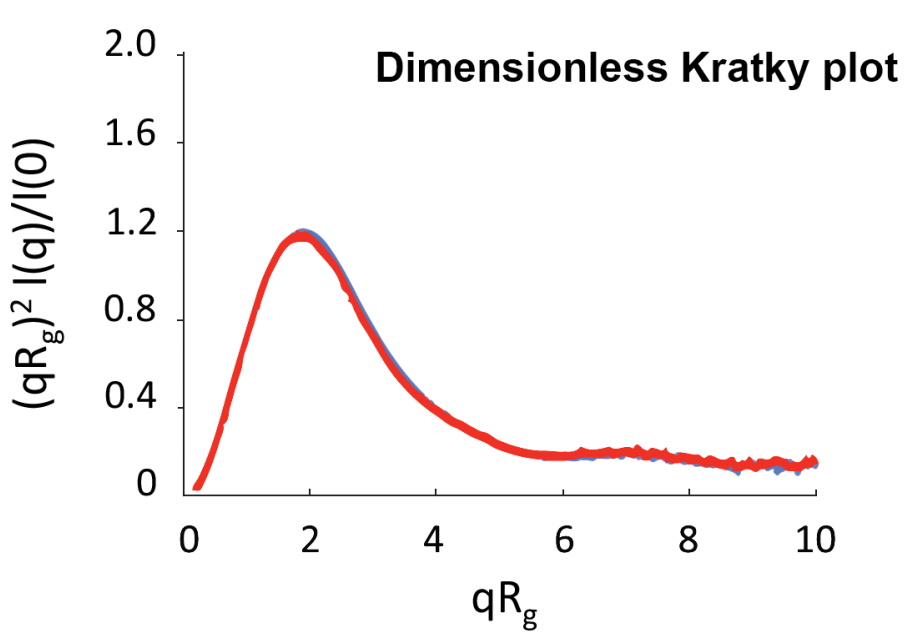

\begin{tabular}{ccc}
\hline & $\mathrm{LC}-\mathrm{H}_{\mathrm{N}} \mathrm{pH} 7$ & $\mathrm{LC}^{-} \mathrm{H}_{\mathrm{N}} \mathrm{pH} \mathrm{4}$ \\
\hline $\mathrm{AUC}$ & & \\
$s(\mathrm{~S})$ & 5.7 & 5.7 \\
$f / f_{0}$ & 1.2 & 1.3 \\
\hline $\mathrm{SAXS}$ & & \\
$\mathrm{R}_{\mathrm{g}}(\AA)$ & 36.8 & 37.8 \\
$\mathrm{D}_{\max }(\AA)$ & 160 & 140 \\
\hline
\end{tabular}

Fig 3. SAXS and analytical ultracentrifugation analysis of $\mathrm{LC}-\mathrm{H}_{\mathrm{N}}$ at $\mathrm{pH} 7$ and $\mathrm{pH}$ 4. A, comparison of the superposition of the logarithm of the SAXS intensities as a function of the amplitude of the diffusion vector $\left[\mathrm{f} / \mathrm{f}_{0}\right.$ $=4 \pi \sin \theta / \lambda]$, for $\mathrm{LC}-\mathrm{H}_{\mathrm{N}}$ at $\mathrm{pH} 7$ (red curve) and $\mathrm{pH} 4$ (blue curve). B, Superposition of the dimensionless Kratky plots of $\mathrm{LC}-\mathrm{H}_{\mathrm{N}}$ at $\mathrm{pH} 7$ (red curve) and pH 4 (blue curve). This representation reveals the type of structure: compact, partially folded or unfolded. C, summary of shape describing parameters obtained from AUC and SAXS: sedimentation coefficient (s, in Svedberg), frictional ratio $\left(f / f_{o}\right)$, radius of gyration $\left(R_{g}\right)$.

doi:10.1371/journal.pone.0153401.g003 


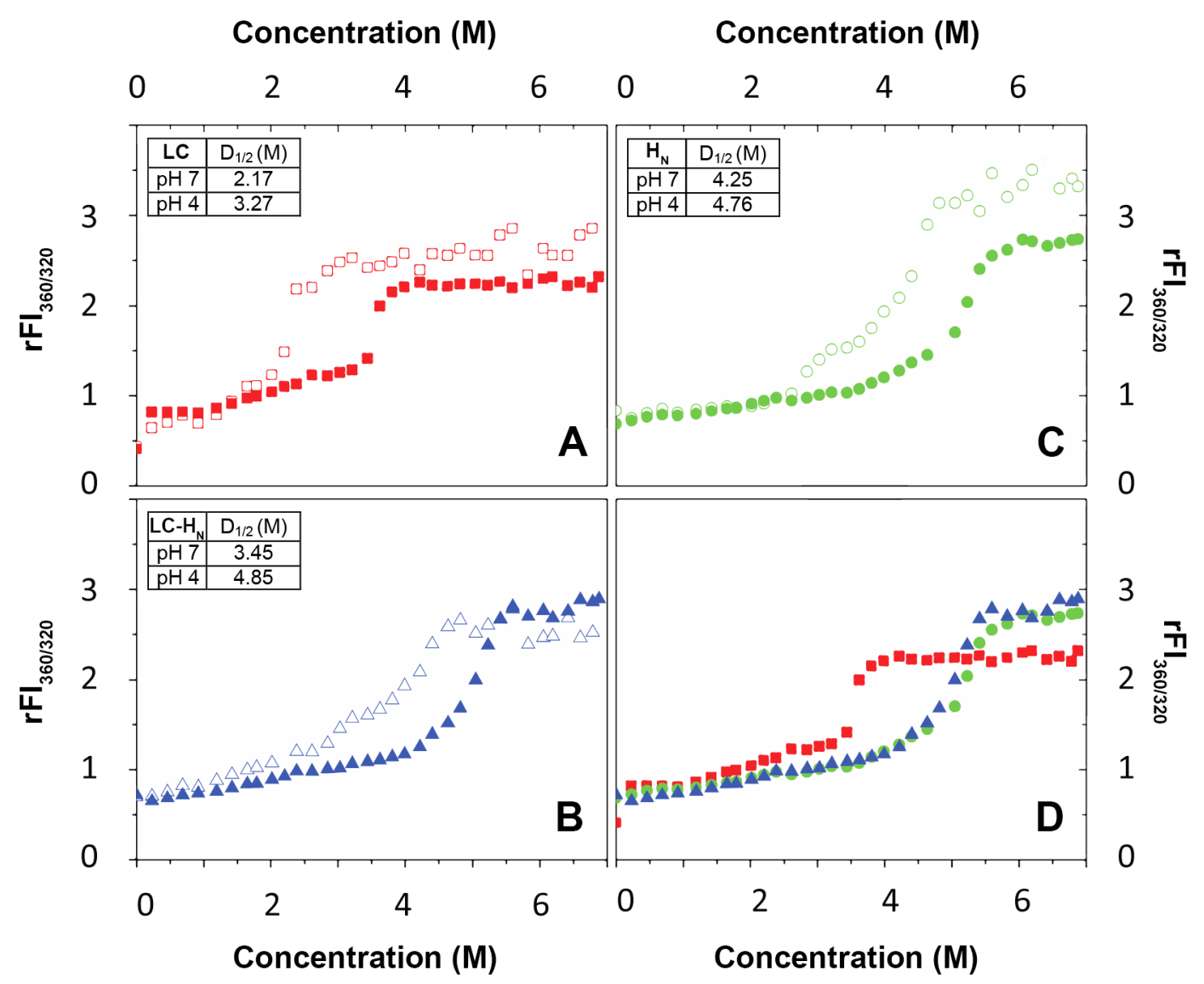

Fig 4. Effect of pH on the stability of LC, $H_{N}$ and $L C-H_{N}$ proteins. GdnHCl-induced denaturation of LC, $H_{N}$ and LC- $H_{N}$ followed by Trp fluorescence at pH 7 and pH 4. $A, B, C$, denaturation curves of $L C, H_{N}$ and $L C-H_{N}$ respectively, at pH 7 (open symbols) and pH 4 (closed symbols). D, superposition of the denaturation curves of $\mathrm{LC}$ (red squares), $\mathrm{H}_{\mathrm{N}}$ (green circles) and LC- $\mathrm{H}_{\mathrm{N}}$ (blue triangles) at $\mathrm{pH}$ 4. Inset, table of thermodynamic parameters $\Delta \mathrm{G}^{0}$ and $\mathrm{D}_{1 / 2}$, for each protein at $\mathrm{pH} 7$ and $\mathrm{pH} 4$.

doi:10.1371/journal.pone.0153401.g004

(Fig 4, inset tables), respectively. This is consistent with the increase of $\Delta \mathrm{G}^{0}$ values extracted from the curves upon acidification. At $\mathrm{pH} 7$ the $\Delta \mathrm{G}^{0}$ are $3.7 \mathrm{kcal}^{\mathrm{mol}}{ }^{-1}, 3.3 \mathrm{kcal} . \mathrm{mol}^{-1}$ and 3.5

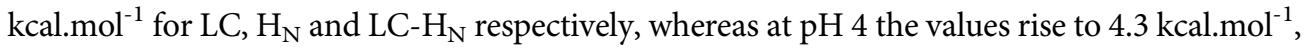
$6.1 \mathrm{kcal}^{\mathrm{mol}}{ }^{-1}$ and $5.7 \mathrm{kcal}^{\mathrm{mol}}{ }^{-1}$, respectively. Interestingly, while the stability of LC slightly increases with the $\mathrm{pH}$ drop from 7 to 4 with a gain in $\Delta \mathrm{G}^{0}$ of $0.6 \mathrm{kcal}^{\mathrm{mol}}{ }^{-1}$, that of $\mathrm{H}_{\mathrm{N}}$ is considerably increased with almost a doubling of its $\Delta G^{0}$. The situation for $L C-H_{N}$ is close to that of $\mathrm{H}_{\mathrm{N}}$ suggesting that the presence of $\mathrm{H}_{\mathrm{N}}$ increases the stability of LC, especially at acidic $\mathrm{pH}$. Altogether, the results show that $\mathrm{LC}$ is less stable than $\mathrm{H}_{\mathrm{N}}$, and that acidic $\mathrm{pH}$ strongly increase the stability of $\mathrm{H}_{\mathrm{N}}$, which then stabilizes LC within the $\mathrm{LC}-\mathrm{H}_{\mathrm{N}}$ protein.

\section{The isolated LC of BoNT/A interacts with a membrane without requiring the presence of $\mathrm{H}_{\mathrm{N}}$}

We characterized previously the interaction of $\mathrm{H}_{\mathrm{N}}$ of BoNT/A with negatively charged lipid vesicles [23]. Here, we investigated the capacity of the isolated LC to interact with a negatively charged membrane (LUV) in the absence of $\mathrm{H}_{\mathrm{N}}$, as a function of $\mathrm{pH}$. The interaction was monitored by three fluorescence methods: intrinsic fluorescence of the Trp of LC, FRET from the Trp of LC towards dansyl groups linked to the phospholipid head-groups of LUV and fluorescence dye recovery upon LUV permeabilization (Fig 5). 

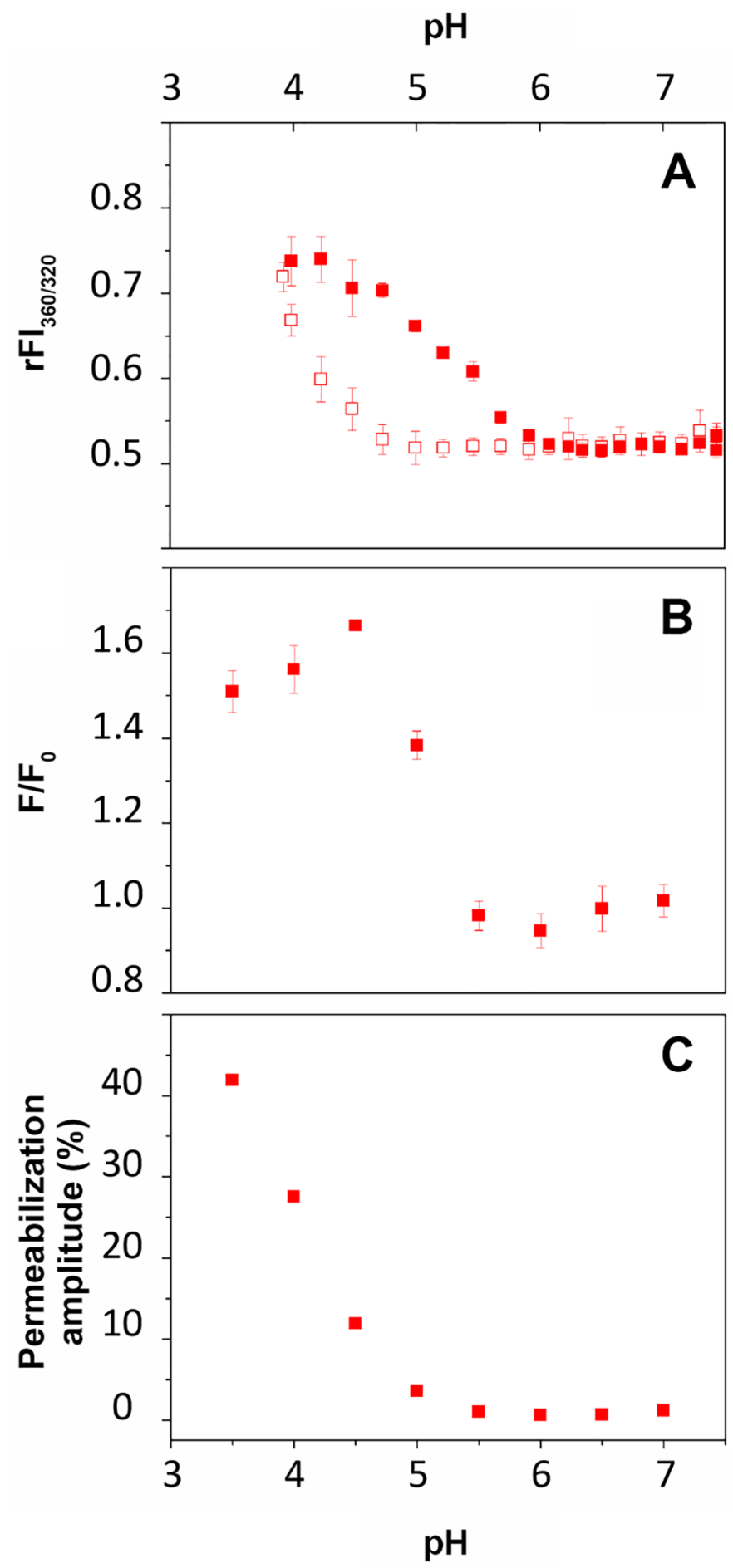

Fig 5. Membrane interaction of LC of BoNT/A as a function of $\mathrm{pH}$. A, ratio of Trp fluorescence intensities at $360 \mathrm{~nm}$ and $320 \mathrm{~nm}$ in solution in absence (open squares) and in presence of LUV (closed squares). B, FRET from LC protein $(0.5 \mu \mathrm{M})$ to dansyl-DHPE-containing LUV $(50 \mu \mathrm{M})$. C, LUV $(100 \mu \mathrm{M})$ permeabilization induced by LC $(0.1 \mu \mathrm{M})$, expressed as percent of permeabilization amplitude reflected the maximum rate of permeabilization achieved for each $\mathrm{pH}$.

doi:10.1371/journal.pone.0153401.g005 
In the presence of LUV, the $\mathrm{rFI}_{360 / 320}$ increases as $\mathrm{pH}$ drops from 6 to 4.2 (Fig 5, top). In the absence of LUV, a similar transition occurs but at more than one $\mathrm{pH}$ unit lower. These results indicate that the environment of the Trp of LC in solution become more polar as $\mathrm{pH}$ decreases. The presence of membrane shifts the transition to higher $\mathrm{pH}$ values due to the partition of the protein from solution to the membrane.

When the Trp of the protein (donors) are close to the dansyl groups in the membrane (acceptor) FRET is detected as an increase of acceptor fluorescence. In the presence of LUV, the Trp intrinsic fluorescence transition we detected correlates nicely with an increase of the FRET signal from $\mathrm{pH} 6$ to 4.5. The increase of the FRET signal upon acidification reveals a closer proximity between the Trp and the polar headgroups of the lipid bilayer and demonstrates the interaction of the protein with the membrane. Together, these data indicate that LC interacts progressively with the LUV as $\mathrm{pH}$ drops from 6 to about 4 .

LC exhibits a pH-dependent capacity to permeabilize the LUV as shown by its ability to induce the release of sulforhodamine B entrapped at self-quenching concentration in the LUV. The efficiency of permeabilization is expressed as the maximum percentage of permeabilization induced by $\mathrm{LC}$ at a given $\mathrm{pH}$ (Fig 5, bottom and Fig 6, top). The permeabilization phenomenon starts below $\mathrm{pH} 5.5,0.5 \mathrm{pH}$ units lower than the appearance of the FRET signal. Altogether, the data suggest that the interaction of $\mathrm{LC}$ with the lipid bilayer involves at least two steps: partition of LC into the interfacial region of the membrane (FRET signal without permeabilization) followed by a deeper penetration into the bilayer, which induce leakage of the dye contained in the LUV (permeabilization).

No permeabilization was observed with negative LUV in the presence of increased $\mathrm{NaCl}$ concentrations (200 mM instead of $100 \mathrm{mM}$ ). Similarly, no permeabilization was observed with LUV made of neutral phospholipids only (S4 Fig). This indicates that permeabilization involves electrostatic interactions between the proteins and negative charges on the membrane.

It is noteworthy that this partition-permeabilization process can occur in the absence of $\mathrm{H}_{\mathrm{N}}$.

\section{$\mathrm{H}_{\mathrm{N}}$ of BoNT/A moderates the propensity of LC to interact with membranes}

Permeabilization and FRET experiments were also performed with the isolated $\mathrm{H}_{\mathrm{N}}$ and the protein $\mathrm{LC}-\mathrm{H}_{\mathrm{N}}$ in order to compare the behavior of both domains isolated or linked by the native inter-domain disulfide bond. Fig 6A-6C show the kinetics of dye release from LUV in the presence of $\mathrm{LC}, \mathrm{H}_{\mathrm{N}}$ and $\mathrm{LC}-\mathrm{H}_{\mathrm{N}}$ at various $\mathrm{pHs}$ from 7 to 3.5. The results are expressed as the percentage of fluorescence increase after addition of the protein to the LUV, with $100 \%$ corresponding to the maximum release obtained by triton $\mathrm{X}-100$. The three proteins show a capacity to destabilize the membrane as $\mathrm{pH}$ drops. $\mathrm{H}_{\mathrm{N}}$ starts to permeabilize the LUV below $\mathrm{pH}$ 5, while the phenomenon starts below pH 5.5 for LC and LC- $\mathrm{H}_{\mathrm{N}}$. However, LC was about twice more efficient than $\mathrm{H}_{\mathrm{N}}$ in permeabilizing the LUV. While maximum dye release reached $40 \%$ for $\mathrm{LC}$, it reached about $15 \%$ for $\mathrm{H}_{\mathrm{N}}$ and $30 \%$ for $\mathrm{LC}-\mathrm{H}_{\mathrm{N}}$. In addition, the transition observed by FRET for the interaction with the membrane (Fig 6D) is more cooperative for LC than for $\mathrm{H}_{\mathrm{N}}$, an intermediate situation being found for $\mathrm{LC}-\mathrm{H}_{\mathrm{N}}$.

Altogether, the data suggest that $\mathrm{H}_{\mathrm{N}}$ moderates the propensity of $\mathrm{LC}$ to interact with and permeabilizes membranes at acidic $\mathrm{pH}$.

\section{Discussion}

How does BoNT/A, a soluble protein, manage to interact with and further penetrate into a membrane is a key issue for its translocation. Here we designed a study using a combination of 

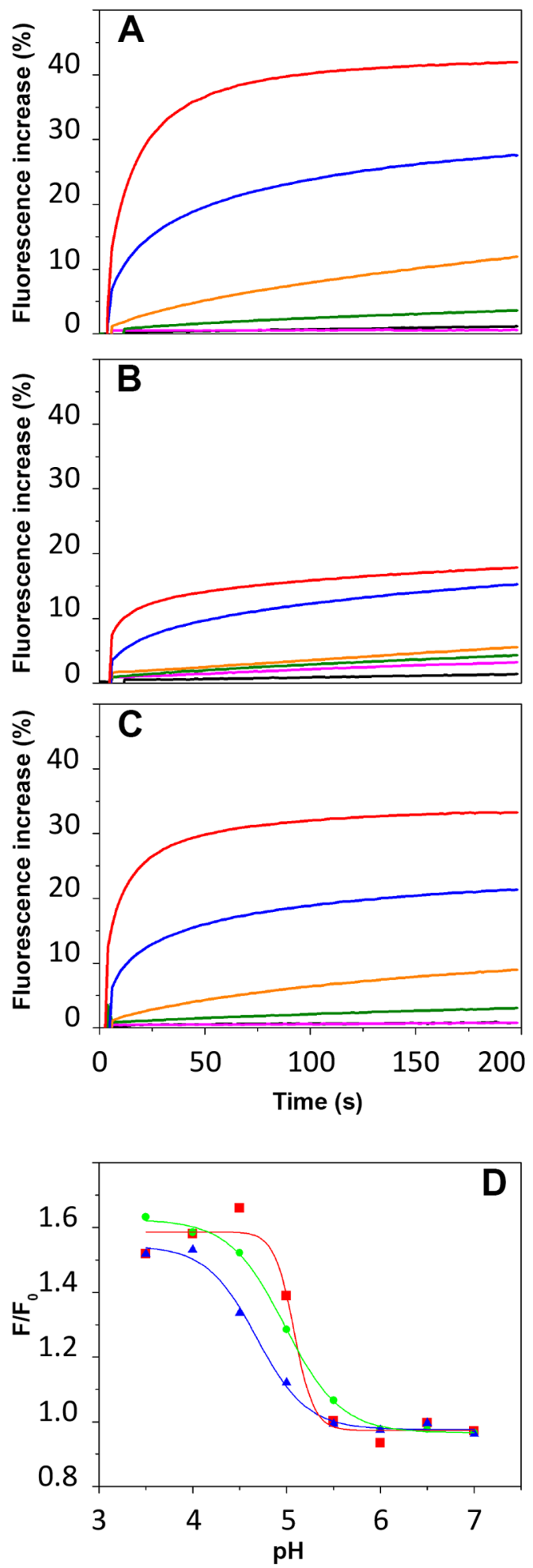

Fig 6. Comparison of permeabilization of, and membrane binding to LUV by $L C, H_{N}$ and LC- $H_{N}$ proteins of BoNT/A. A, B, C, Kinetics of SRB leakage from LUV $(100 \mu M)$ after addition of LC $(A), H_{N}(B)$ and $\mathrm{LC}-\mathrm{H}_{\mathrm{N}}(\mathrm{C})(0.1 \mu \mathrm{M})$ at $\mathrm{pH} 7$ (black), $\mathrm{pH} 6$ (pink), $\mathrm{pH} 5$ (green), $\mathrm{pH} 4.5$ (orange), $\mathrm{pH} 4$ (blue) and pH 3.5 (red). S3 Fig shows absence of SRB leakage in the absence of proteins and $100 \%$ SRB release after Triton X-100 addition. D, FRET from LC (red), $\mathrm{H}_{\mathrm{N}}$ (green) and $\mathrm{LC}-\mathrm{H}_{\mathrm{N}}$ (blue) at $0.5 \mu \mathrm{M}$ to dansyl-DHPE-containing $\mathrm{LUV}$ at $50 \mu \mathrm{M}$.

doi:10.1371/journal.pone.0153401.g006 
spectroscopic methods to probe the effect of the $\mathrm{pH}$ on the structural properties and membrane interaction of the $\mathrm{LC}$ and $\mathrm{H}_{\mathrm{N}}$ of BoNT/A, alone or covalently linked together.

The acidic state in solution of $\mathrm{LC}$ and $\mathrm{H}_{\mathrm{N}}$, competent for membrane interaction, is characterized by increased stability without any major conformational change. Upon acidification, no significant secondary or tertiary structure change in solution can be observed for either LC or $\mathrm{H}_{\mathrm{N}}$, alone or covalently linked by the native inter-domain disulfide bond (Fig 2). This observation is in agreement with previous studies that reported no major structural change upon acidification for LC [32,33], $\mathrm{H}_{\mathrm{N}}[23,34]$ or the entire toxin [35,36]. Here, in contrast with previous studies on the LC and the whole toxin, we investigated a wide range of $\mathrm{pHs}$ from 7 down to 3 . Interestingly, a gain of tertiary constraints seems to occur for the $\mathrm{LC}-\mathrm{H}_{\mathrm{N}}$ protein at low $\mathrm{pH}$ (Fig 2). This observation is in agreement with the increase of stability found for this protein as $\mathrm{pH}$ drops (Fig 4). Overall, the data suggest that $\mathrm{LC}$ and $\mathrm{H}_{\mathrm{N}}$, isolated or linked together, do not undergo large $\mathrm{pH}$-induced conformational changes. Nevertheless, our observations do not exclude local conformational changes, which would favor membrane partitioning. Indeed, Trp fluorescence changes can be seen as $\mathrm{pH}$ drops both for LC (Fig 5, top panel, open squares) and $\mathrm{H}_{\mathrm{N}}[23,34]$.

However, an important finding of the thermodynamic analysis is that the stability of the domains in solution is increased as $\mathrm{pH}$ drops. Indeed, $\mathrm{GdnHCl}$-induced unfolding experiments showed that $\mathrm{H}_{\mathrm{N}}$ is more stable than $\mathrm{LC}$ and that the stability of $\mathrm{H}_{\mathrm{N}}$ is considerably increased at low $\mathrm{pH}$, thus apparently contributing to an increased stability of $\mathrm{LC}$ within $\mathrm{LC}-\mathrm{H}_{\mathrm{N}}$.

LC in its acidic state interacts and permeabilizes anionic phospholipid membranes in the absence of $\mathrm{H}_{\mathrm{N}}$. Tables 2 and 3 summarize the features of the acidic states of $\mathrm{LC}$ and $\mathrm{H}_{\mathrm{N}}$ in solution and in the presence of membranes. Considering LC alone, the data strongly suggest that

Table 2. Features of $L C$ and $H_{N}$ upon acidification in solution.

\begin{tabular}{lcc}
\hline \multicolumn{1}{c}{ Features in solution } & LC & $\mathbf{H}_{\mathbf{N}}$ \\
\hline \multicolumn{1}{c}{ Trp $^{1}$} & Exposed from pH 4.7 to 3.8 & Buried from $\mathrm{pH} 6.2$ to $3.8^{2}$ \\
\hline Secondary structure & Unchanged & Unchanged \\
Tertiary structure ${ }^{3}$ & Increased & Unchanged \\
$\quad$ Stability & Increased & Increased \\
Influence over the other domain & $?$ & Stabilization \\
\hline${ }^{1}$ Trp fluorescence & \\
${ }^{2}$ not shown & & \\
${ }^{3} \mathrm{CD}$ & & \\
${ }^{4} \mathrm{GdnHCl}$ denaturation & & \\
\hline
\end{tabular}

doi:10.1371/journal.pone.0153401.t002

Table 3. Features of $L C$ and $H_{N}$ upon acidification in the presence of membranes (LUV).

\begin{tabular}{|c|c|c|}
\hline Features in presence of LUV & LC & $\mathbf{H}_{\mathrm{N}}$ \\
\hline $\operatorname{Trp}^{1}$ & Exposed from pH 5.9 to 4.2 & Buried from $\mathrm{pH} 6.2$ to $3.8^{2}$ \\
\hline Membrane binding ${ }^{3}$ & From pH 5.5 to 4.5 & From pH 5.5 to 3.5 \\
\hline Membrane permeabilization ${ }^{4}$ & From 5 to 3.5 & From 4.5 to 3.5 \\
\hline Influence over the other domain & $?$ & Moderates membrane interaction \\
\hline \multicolumn{3}{|l|}{${ }^{1} \operatorname{Trp}$ fluorescence } \\
\hline \multicolumn{3}{|l|}{${ }^{2}$ Not shown } \\
\hline \multicolumn{3}{|l|}{${ }^{3} \mathrm{FRET}$} \\
\hline${ }^{4}$ Fluorescent dye release from $\mathrm{Ll}$ & & \\
\hline
\end{tabular}

doi:10.1371/journal.pone.0153401.t003 
the presence of the membrane displaces the equilibrium toward the acidic state of LC and its transition into a membrane-bound state (Fig $5 \mathrm{~A}$ and $5 \mathrm{~B}$ ). Then, further acidification provokes permeabilization of the membrane by LC, indicative of a state in which LC destabilizes the lipid bilayer (Fig 5, bottom and Fig 6, top). The striking feature of this interaction is that membrane permeabilization by LC occurs without the help of another domain or component of the toxin or cellular machinery $[37,38]$. This finding infers the following question: what is the role of $\mathrm{H}_{\mathrm{N}}$ for membrane interaction and thereby for translocation?

$\mathrm{H}_{\mathrm{N}}$ of BoNT/A moderates the propensity of LC to interact with membranes at acidic $\mathrm{pH}$. The data obtained here with the $\mathrm{LC}-\mathrm{H}_{\mathrm{N}}$ protein bring three observations: $\mathrm{H}_{\mathrm{N}}$ contributes to the stabilization of $\mathrm{LC}$ at neutral and acidic $\mathrm{pH}$ in solution, it reduces the cooperativity of the binding of $\mathrm{LC}$ with membranes and it reduces the efficiency of membrane permeabilization of the membrane by LC. It is likely that at a given $\mathrm{pH}$ the lipid bilayer destabilization by LC is reduced by the presence of $\mathrm{H}_{\mathrm{N}}$. We found previously that this capacity of $\mathrm{H}_{\mathrm{N}}$ was due to its $\mathrm{N}$ terminal belt that surrounds LC blocking its catalytic site [23]. One could hypothesize that the stabilization of $\mathrm{LC}$ by $\mathrm{H}_{\mathrm{N}}$ that we observed in solution, also occurs during interaction with the membrane, thereby limiting membrane penetration and destabilization by LC. Thus, $\mathrm{H}_{\mathrm{N}}$ would act as a chaperone-like domain, probably both through its belt and the wide interfacial region between the two domains. These two contact surfaces between the domains certainly represent major constraints over LC.

$\mathrm{LC}$ and $\mathrm{H}_{\mathrm{N}}$ of BoNT/A possess structural and physico-chemical properties distinct from that of other translocating toxins. This is inferred by a comparison with the mechanisms of action of other translocating toxins: monomeric $\left(\mathrm{AB}_{\mathrm{RTC}}\right)$ and multimeric (anthrax, binary and $\mathrm{AB}_{5}$ toxins). The enzymatic components of anthrax toxin need the help of the membrane protective antigen hepta/octamer that catalyzes the unfolding of these enzymatic components and offers them a protein pore for their passage through the membrane [39]. Ricin and $A_{5}$ toxins such as Shiga toxin and Cholera toxin hijack the ERAD system in the endoplasmic reticulum to translocate into the cytosol $[37,38]$.

It has been shown by electron and atomic force microscopies that BoNT/B and E [40,41] form multimers. In our observations by SAXS and AUC, no multimers were found in solution whatever the $\mathrm{pH}$. Multimerization may depend highly on experimental conditions. In any case, one cannot rule out yet whether multimers of BoNT must form to ensure translocation.

The catalytic domain (C) of the diphtheria toxin, which is also a RTC toxin, interacts and permeabilizes the membrane of LUV with much better efficacy with the help of the translocation domain (T) $[19,42]$. In this case, $\mathrm{T}$ acts as a chaperone stabilizing successively several partially folded states of the $\mathrm{C}$ domain. Further description of this process for BoNT/A would require the determination of the structure of translocation intermediates.

Both the $\mathrm{C}$ and $\mathrm{T}$ domains of diphtheria toxin, which correspond functionally to $\mathrm{LC}$ and $\mathrm{H}_{\mathrm{N}}$, undergo remarkable conformational changes upon acidification (in solution and in presence of membrane) to achieve a molten globule state needed for the membrane interaction $[43,44]$. We show by CD and SAXS (Figs 2 and 3 ) that $\mathrm{LC}$ and $\mathrm{H}_{\mathrm{N}}$ of BoNT/A do not display any major conformational changes upon acidification in solution. This observation is supported by other works $[32,33,35,36]$. In addition, we found that $\mathrm{LC}$ has by itself a high propensity to bind (Fig $5 \mathrm{~B}$ ) and penetrate (Fig $5 \mathrm{C}$ ) a membrane at acidic $\mathrm{pH}$. The results suggest that the role of $\mathrm{H}_{\mathrm{N}}$ is to negatively regulate this propensity. We showed previously that the belt region of $\mathrm{H}_{\mathrm{N}}$ is responsible for the negative regulation of the interaction of $\mathrm{H}_{\mathrm{N}}$ with the membrane [23]. As a consequence, it is very likely that LC of BoNT/A interacts with both the membrane and $\mathrm{H}_{\mathrm{N}}$ during the first steps of its translocation. This is compatible with the cleft model proposed earlier by Montecucco [15,22], who showed also that LC is able to bind phospholipids. Single channel conductance measurements showed that LC blocks the ion channel formed 
in the membrane by $\mathrm{H}_{\mathrm{N}}$ for BoNT/A and BoNT/E during translocation [45]. Reconciliation of this model with our observations would imply that the channel made by $\mathrm{H}_{\mathrm{N}}$ would be closed by the passage of LC between the lipids of the bilayer and one of the faces of $\mathrm{H}_{\mathrm{N}}$ embedded in the membrane.

\section{Supporting Information}

S1 Fig. Coomassie blue stained SDS-PAGE of recombinant proteins used in this study. A, LC- $\mathrm{H}_{\mathrm{N}}, \mathrm{H}_{\mathrm{N}}$ and LC in reducing and non-reducing conditions (+ or- $\beta$-mercaptoethanol, ( $\beta$ $\mathrm{ME})$ ). B; $\mathrm{LC}-\mathrm{H}_{\mathrm{N}}$ was treated with trypsin before mixing with loading buffer + or $-\beta-\mathrm{ME}$ and analyzed on the SDS-PAGE. On each gel, Lane 1 is a ladder of protein molecular weight markers shown in $\mathrm{kDa}$. The results show that the proteolytic cleavage site between $\mathrm{LC}$ and $\mathrm{H}_{\mathrm{N}}$ is uncleaved in the recombinant protein before trypsin treatment and cleaved after. The disulfide bridge linking both domains is intact as well and reduced by $\beta$-ME. (TIF)

S2 Fig. Guinier representations of the SAXS curves obtained for $\mathrm{LC}-\mathrm{H}_{\mathrm{N}}$ at $\mathrm{pH} 7$ and $\mathrm{pH} 4$. These representations were calculated using Primus. They correspond to the logarithm of the SAXS intensity $(\log I)$ as a function of the square of the diffusion vector amplitude $\left(\mathrm{q}^{2}\right)$, plotted up to a $\mathrm{q}^{*} \mathrm{Rg}$ limit of 1.3. The slope of these representations represents the radius of gyration $(\mathrm{Rg})$ of the molecule.

S3 Fig. Representative control for the LUV permeabilization experiments. Self fluorescence quenching of SRB entrapped inside the LUV define $0 \%$ fluorescence. The LUV are incubated at varying $\mathrm{pH}$ for over $150 \mathrm{~s}$. The absence of fluorescence increase indicates the absence of SRB leakage from the LUV (in the absence of protein addition). After $150 \mathrm{~s}$, the addition of Triton $\mathrm{X}-100$ solubilizes the membrane of all the LUV and releases the entrapped SRB, leading to dequenching and maximum fluorescence (100\%).

S4 Fig. Effect of LUV surface charge on membrane permeabilization by $L C, H_{N}$ and LC- $\mathbf{H}_{\mathbf{N}}$. Kinetics of LUV leakage of LC, $\mathrm{H}_{\mathrm{N}}$ and LC- $\mathrm{H}_{\mathrm{N}}$ at $\mathrm{pH} 7$ (black lines), pH 5 (green), and pH 4.5 (orange) in presence of neutral LUV (left) or negatively charged LUV with $200 \mathrm{mM}$ $\mathrm{NaCl}$ (right). The arrows indicate the addition of protein and triton X-100 that gives the maximum of dye release.

S1 Table. Thermodynamic parameters for the GdnHCl-induced unfolding transitions of LC (A), $H_{N}(B)$ and $L C-H_{N}(C)$ protein of BoNT/A at pH 7, 6, 5, 4, 3.5. $\Delta \mathrm{G}_{0}$ is the free energy in the absence of chaotropic agent, $\mathrm{D}$ is the denaturant concentration and $m$ is the coefficient of dependence of free energy on denaturant concentration. $m$ is related to the variation of the solvent-accessible surface area between the folded and unfolded states.

(DOCX)

\section{Acknowledgments}

We thank Nicolas Durafourc and Maité Paternostre for help with LUV preparation. For help with protein production and purification we thank Cassandra Porebski. For help with AUC experiments we thank Bertrand Raynal. AA was supported by DGA and CEA. This work was funded by the joint ministerial program of $R \& D$ against CBRNE threats. SIMOPRO is a member of the Laboratory of Excellence LERMIT supported by a grant from the Agence Nationale 
de la Recherche (ANR-10-LABX-33). The funders had no role in study design, data collection and analysis, decision to publish, or preparation of the manuscript.

\section{Author Contributions}

Conceived and designed the experiments: AA SP BB PE JP SZJ AC DG. Performed the experiments: AA AG SP BB JP SZJ AC. Analyzed the data: AA JB BB PE JP SZJ AC DG. Contributed reagents/materials/analysis tools: AA AG JB SP BB PE JP SZJ AC DG. Wrote the paper: AA JB SP JP SZJ AC DG.

\section{References}

1. Poulain B, Popoff MR, Molgo J. How do the Botulinum Neurotoxins block neurotransmitter release: from botulism to the molecular mechanism of action. The Botulinum J. 2008; Vol.1: 14-87.

2. Arnon SS, Schechter R, Inglesby TV, Henderson DA, Bartlett JG, Ascher MS, et al. Botulinum toxin as a biological weapon: medical and public health management. JAMA. 2001; 285: 1059-1070. PMID: 11209178

3. Schiavo G, Matteoli M, Montecucco C. Neurotoxins affecting neuroexocytosis. Physiol Rev. 2000; 80: 717-766. PMID: 10747206

4. Lacy DB, Tepp W, Cohen AC, DasGupta BR, Stevens RC. Crystal structure of botulinum neurotoxin type A and implications for toxicity. Nat Struct Biol. 1998; 5: 898-902. PMID: 9783750

5. Rossetto O, Montecucco C. Presynaptic neurotoxins with enzymatic activities. Handb Exp Pharmacol. 2008; 184: 129-170. PMID: 18064414

6. Kumaran D, Eswaramoorthy S, Furey W, Navaza J, Sax M, Swaminathan S. Domain organization in Clostridium botulinum neurotoxin type $\mathrm{E}$ is unique: its implication in faster translocation. J Mol Biol. 2009; 386: 233-245. doi: 10.1016/j.jmb.2008.12.027 PMID: 19118561

7. Swaminathan S, Eswaramoorthy S. Structural analysis of the catalytic and binding sites of Clostridium botulinum neurotoxin B. Nat Struct Biol. 2000; 7: 693-699. PMID: 10932256

8. Montecucco C. How do tetanus and botulinum toxins bind to neuronal membranes? Trends in Biochemical Sciences. 1986; 11: 314-317.

9. Rummel A, Eichner T, Weil T, Karnath T, Gutcaits A, Mahrhold S, et al. Identification of the protein receptor binding site of botulinum neurotoxins $B$ and $G$ proves the double-receptor concept. Proc Nat Acad Sci U S A. 2007; 104: 359-364. PMID: 17185412

10. Rummel A. Double receptor anchorage of botulinum neurotoxins accounts for their exquisite neurospecificity. Curr Top Microbiol Immunol. 2013; 364: 61-90. doi: 10.1007/978-3-642-33570-9_4 PMID: 23239349

11. Binz T, Rummel A. Cell entry strategy of clostridial neurotoxins. Journal of Neurochemistry. 2009; 109: 1584-1595. doi: 10.1111/j.1471-4159.2009.06093.x PMID: 19457120

12. Harper CB, Martin S, Nguyen TH, Daniels SJ, Lavidis NA, Popoff MR, et al. Dynamin inhibition blocks botulinum neurotoxin type A endocytosis in neurons and delays botulism. J Biol Chem. 2011; 286: 35966-35976. doi: 10.1074/jbc.M111.283879 PMID: 21832053

13. Hoch DH, Romero-Mira M, Ehrlich BE, Finkelstein A, DasGupta BR, Simpson LL. Channels formed by botulinum, tetanus, and diphtheria toxins in planar lipid bilayers: relevance to translocation of proteins across membranes. Proc Natl Acad Sci U S A. 1985; 82: 1692-1696. PMID: 3856850

14. Montal M. Translocation of botulinum neurotoxin light chain protease by the heavy chain protein-conducting channel. Toxicon. 2009; 54: 565-569. doi: 10.1016/j.toxicon.2008.11.018 PMID: 19111565

15. Montecucco C, Schiavo G, Dasgupta BR. Effect of $\mathrm{pH}$ on the interaction of botulinum neurotoxins $A, B$ and E with liposomes. Biochem J. 1989; 259: 47-53. PMID: 2719650

16. Humeau Y, Doussau F, Grant NJ, Poulain B. How botulinum and tetanus neurotoxins block neurotransmitter release. Biochimie. 2000; 82: 427-446. PMID: 10865130

17. Geny B, Popoff MR. Bacterial protein toxins and lipids: pore formation or toxin entry into cells. Biol Cell. 2006; 98: 667-678. PMID: 17042742

18. Jiang J, Pentelute BL, Collier RJ, Zhou ZH. Atomic structure of anthrax protective antigen pore elucidates toxin translocation. Nature. 2015; 521: 545-549. doi: 10.1038/nature14247 PMID: 25778700

19. Chassaing A, Pichard S, Araye-Guet A, Barbier J, Forge V, Gillet D. Solution and membrane-bound chaperone activity of the diphtheria toxin translocation domain towards the catalytic domain. FEBS $\mathrm{J}$. 2011; 278: 4516-4525. doi: 10.1111/j.1742-4658.2011.08053.x PMID: 21332941 
20. Fischer A, Montal M. Single molecule detection of intermediates during botulinum neurotoxin translocation across membranes. Proc Natl Acad Sci U S A. 2007; 104: 10447-10452. PMID: 17563359

21. Koriazova LK, Montal M. Translocation of botulinum neurotoxin light chain protease through the heavy chain channel. Nat Struct Biol. 2003; 10: 13-18. PMID: 12459720

22. Montecucco C, Schiavo G, Gao Z, Bauerlein E, Boquet P, DasGupta BR. Interaction of botulinum and tetanus toxins with the lipid bilayer surface. Biochem J. 1988; 251: 379-383. PMID: 3401212

23. Galloux M, Vitrac H, Montagner C, Raffestin S, Popoff MR, Chenal A, et al. Membrane Interaction of botulinum neurotoxin $A$ translocation $(T)$ domain. The belt region is a regulatory loop for membrane interaction. J Biol Chem. 2008; 283: 27668-27676. doi: 10.1074/jbc.M802557200 PMID: 18693250

24. Baldwin MR, Bradshaw M, Johnson EA, Barbieri JT. The C-terminus of botulinum neurotoxin type A light chain contributes to solubility, catalysis, and stability. Protein Expr Purif. 2004; 37: 187-195. PMID: 15294297

25. Stura EA, Le Roux L, Guitot K, Garcia S, Bregant S, Beau F, et al. Structural framework for covalent inhibition of Clostridium botulinum neurotoxin A by targeting Cys165. J Biol Chem. 2012; 287: 3360733614. PMID: 22869371

26. Fu Z, Chen S, Baldwin MR, Boldt GE, Crawford A, Janda KD, et al. Light chain of botulinum neurotoxin serotype A: structural resolution of a catalytic intermediate. Biochemistry. 2006; 45: 8903-8911. PMID: 16846233

27. Schuck P. Size-distribution analysis of macromolecules by sedimentation velocity ultracentrifugation and lamm equation modeling. Biophys J. 2000; 78: 1606-1619. PMID: 10692345

28. Chenal A, Savarin P, Nizard P, Guillain F, Gillet D, Forge V. Membrane protein insertion regulated by bringing electrostatic and hydrophobic interactions into play. A case study with the translocation domain of diphtheria toxin. J Biol Chem. 2002; 277: 43425-43432. PMID: 12193591

29. Montagner C, Perier A, Pichard S, Vernier G, Menez A, Gillet D, et al. Behavior of the N-terminal helices of the diphtheria toxin T domain during the successive steps of membrane interaction. Biochemistry. 2007; 46: 1878-1887. PMID: 17249698

30. Nozaki Y. The preparation of guanidine hydrochloride. Methods Enzymol. 1972; 26: 43-50. PMID: 4680720

31. Chenal A, Karst JC, Sotomayor Perez AC, Wozniak AK, Baron B, England P, et al. Calcium-induced folding and stabilization of the intrinsically disordered RTX domain of the CyaA toxin. Biophys J. 2010; 99: 3744-3753. doi: 10.1016/j.bpj.2010.10.016 PMID: 21112299

32. Cai S, Kukreja R, Shoesmith S, Chang TW, Singh BR. Botulinum neurotoxin light chain refolds at endosomal pH for its translocation. Protein J. 2006; 25: 455-462. PMID: 17115255

33. Li L, Singh BR. Spectroscopic analysis of $\mathrm{pH}$-induced changes in the molecular features of type A botulinum neurotoxin light chain. Biochemistry. 2000; 39: 6466-6474. PMID: 10828961

34. Lai B, Agarwal R, Nelson LD, Swaminathan S, London E. Low pH-induced pore formation by the T domain of botulinum toxin type $\mathrm{A}$ is dependent upon $\mathrm{NaCl}$ concentration. J Membr Biol. 2010; 236: 191-201. doi: 10.1007/s00232-010-9292-z PMID: 20711775

35. Eswaramoorthy S, Kumaran D, Keller J, Swaminathan S. Role of metals in the biological activity of Clostridium botulinum neurotoxins. Biochemistry. 2004; 43: 2209-2216. PMID: 14979717

36. Fu FN, Busath DD, Singh BR. Spectroscopic analysis of low $\mathrm{pH}$ and lipid-induced structural changes in type $A$ botulinum neurotoxin relevant to membrane channel formation and translocation. Biophys Chem. 2002; 99: 17-29. PMID: 12223236

37. Falguieres $\mathrm{T}$, Johannes L. Shiga toxin $\mathrm{B}$-subunit binds to the chaperone BiP and the nucleolar protein B23. Biol Cell. 2006; 98: 125-134. PMID: 15853775

38. Spooner RA, Lord JM. How ricin and Shiga toxin reach the cytosol of target cells: retrotranslocation from the endoplasmic reticulum. Curr Top Microbiol Immunol. 2012; 357: 19-40. doi: 10.1007/82 2011_154 PMID: 21761287

39. Feld GK, Brown MJ, Krantz BA. Ratcheting up protein translocation with anthrax toxin. Protein Sci. 2012; 21: 606-624. doi: 10.1002/pro.2052 PMID: 22374876

40. Schmid MF, Robinson JP, DasGupta BR. Direct visualization of botulinum neurotoxin-induced channels in phospholipid vesicles. Nature. 1993; 364: 827-830. PMID: 7689178

41. Sun S, Tepp WH, Johnson EA, Chapman ER. Botulinum neurotoxins $B$ and $E$ translocate at different rates and exhibit divergent responses to GT1b and low pH. Biochemistry. 2012; 51: 5655-5662. PMID: 22720883

42. Wang $\mathrm{Y}$, Malenbaum SE, Kachel K, Zhan H, Collier RJ, London E. Identification of shallow and deep membrane-penetrating forms of diphtheria toxin $T$ domain that are regulated by protein concentration and bilayer width. J Biol Chem. 1997; 272: 25091-25098. PMID: 9312118 
43. Hammond K, Caputo GA, London E. Interaction of the membrane-inserted diphtheria toxin T domain with peptides and its possible implications for chaperone-like T domain behavior. Biochemistry. 2002; 41: 3243-3253. PMID: 11863463

44. Ren J, Kachel K, Kim H, Malenbaum SE, Collier RJ, London E. Interaction of diphtheria toxin T domain with molten globule-like proteins and its implications for translocation. Science. 1999; 284: 955-957. PMID: 10320374

45. Montal M. Botulinum neurotoxin: a marvel of protein design. Annu Rev Biochem. 2010; 79: 591-617. doi: 10.1146/annurev.biochem.051908.125345 PMID: 20233039 